\title{
SÖZLÜ GELENEKTE NESİR ANLATILARIN TÜR SORUNU
}

\author{
Mehmet Emin BARS ${ }^{1}$
}

\begin{abstract}
$\ddot{O Z Z}$
Folklorda tür konusu en fazla sorgulanan alanlardan biridir. Ülkemizde yapılan türsel tasniflerde, yöntemsel sorunlarla birlikte, kendi içlerinde ve birbirleriyle çelişkili tanım ve yorumların yapıldığı görülmektedir. Özellikle Türk halk bilimi araştırmacılarının belli bir tür belirlemesinde Avrupalı-Amerikalı araştırmacıların kendi ürünleri üzerinde yaptıkları araştırmalara dayalı olarak yaptıkları tür tasnif ve tanımlamalarına bakarak kendi kültürümüzün ürünlerini bunlara uydurmaya çalışıp benzer tür tasnifleri yapmaları sorunu çözmek yerine daha da karmaşı bir yapıya sokmaktadır. Türsel adlandırmalar hangi ölçütler göz önünde bulundurularak yapılırsa yapılsın, yapılan her tanımlama bazı problemler taşıyacaktır. Yapılan değerlendirmeler dış gerçekliği bire bir yansıtmaktan çok, onu anlamlandırmaya yönelik bir soyutlama olmanın ötesinde bir anlam taşımayacaktır. Bu çalışmada folklor ürünlerinin nesir anlatıları bağlamında tür sorunu ele alınmıştır. Genetik olarak birbirine bağlı olan folklor nesir ürünlerini kesin çizgilerle ayırmak çok güçtür, aslında bazı durumlarda da gereksizdir. Folklor ürünlerinin türleri ilk anlatıldığı toplumlarda belirgin biçimde açıktır. Belli bir türsel sınıflandırma yapmak temelinde yanlış değildir. Ancak her kültür için ortak bir tür tanımına ulaşmaya çalışmak yanlış olabilmektedir. Bir anlatının tür kavramında değerlendirilmesi için belli bir geleneğe sahip olması gerekir.
\end{abstract}

Anahtar Kelimeler: tür, gelenek, folklor, sözlü.

\section{The Genre Problem Of The Prose Narratives In Oral Tradition}

\begin{abstract}
The folklore genre is one of the most questioned areas. It is seen that, in the speciesrelated classifications made in our country, there are contradictory definitions and interpretations within themselves and with each other along with methodological problems. Especially by looking at the classification and description of the genres of European-American researchers of Turkish folkloric researchers, genre sorting introduces an even more complex structure instead of solving the problem. Every definition made will have some problems, regardless of what criteria are taken into account when naming the species. The evaluations made will not reflect the external reality one by one. In this study, the problem of genre is discussed in the prose of folklore products. It is very difficult to separate genetically linked folklore prose products with precise lines, in fact it is unnecessary in some cases. It is very difficult to separate genetically linked folklore prose products with precise lines, in fact it is unnecessary in some cases. Forms of folklore products are evidently clear in the
\end{abstract}

\footnotetext{
${ }^{1}$ Yrd. Doç. Dr. Bingöl Üniversitesi Fen-Edebiyat Fakültesi Türk Dili ve Edebiyatı Anabilim Dal1. m_e_bars_21@hotmail.com.
} 


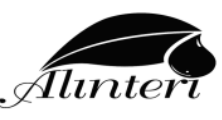

Cilt: 1 Sayı: 2 Yıl: 2017

communities first described. It is not wrong on the basis of a certain species classification. However, it may be wrong to try to reach a common species definition for every culture. A product must have a certain tradition to be considered in the concept of species.

Key Words: genre, tradition, folklore, verbal.

\section{GİRIŞ}

Bugüne kadar folklor ürünlerinin nesir türleri üzerinde belirli ölçütlere göre çeşitli tasnifler yapılmış, bu tasnif ölçütleri kavramsallaştırılmış, farklı folklorik üretimler için genel geçer hale getirilmeye çalışılmıştır. Türk halk biliminin günümüzdeki önemli problemlerinden birini "anlatı türü" oluşturmaktadır. Tür problemi zaman zaman farklı karakterler kazanmış ve çeşitli yaklaşımlarla tartışılmış olmasına rağmen sorunun çözümünde fazla bir ilerleme kaydedildiği söylenemez. Folklor araştırmacılarını en çok meşgul eden, çoğu kez farklı görüşlerin ortaya atılmasına neden olan konulardan biri olan tür (ve aynı zamanda şekil) teriminden ne anlaşılması gerektiği öncelikle belirlenmelidir. Tür sorunu sadece nesir anlatılarda karşımıza çıkmamakta, nazım türünde de benzer sorunlar bulunmaktadır. Örneğin, Onay, halk şiirlerini şekil ve nev'e (türe) göre ayırırken kullandığı ölçütleri belirtmez. Sadece bu ayırımda teganniyi de gözden uzak tutulmaması gerektiğini belirtir (Onay, 1996: 3). Çobanoğlu, âşık şiirinin türünün belirlenmesinde şekil, ezgi, hacim ve icra bağlamını göz önünde bulundurur (Çobanoğlu, 2000: 14). Oğuz, halk şiirinde şekil kavramından dışarıdan görülebilir özelliklerin, tür kavramından da konu ve ezginin anlaşılması gerektiğini düşünür (Oğuz, 2001: 15). Nesir alanında da benzer yaklaşımlar görülmektedir. Aça-Ercan, nesir anlatılardan mit, efsane ve masalı tür olarak ele alırken bunların ayırt edici özelliklerini "inanma, zaman, yer, kabul ediş tavrı ve temel karakterler"'ine göre ayırır (Aça- Ercan, 2006: 117). Rayman (2010), halk edebiyatının anlatı türlerini sınıflandırırken hangi ölçütlere göre bu türleri ayırdığını açıklamaz. Benzer şekilde Boratav (1999), halk edebiyatı türlerini tanımlarken bunların çeşitli özelliklerini sıralar. Tür tasnifindeki ölçütlerin ne olması gerektiği üzerinde durmaz.

Folklorda tür konusu en fazla sorgulanan alanlardan biridir. Ülkemizde yapılan türsel tasniflerde, yöntemsel sorunlarla birlikte, kendi içlerinde ve birbirleriyle çelişkili tanım ve yorumların yapıldığ 1 görülmektedir. Oğuz'a göre "Halk şiirinde tür ve şekil sorunlarına, son derece sinırlı bilgi ve belge ile günümüzden yetmiş-seksen yıl önce eğilen ve bu alanda iki monografi yazan Ahmet Talat Onay'ın, zamanı için oldukça cesaretli ve başarll çalışmasının yöntemi ve bulguları, bu konuda kendisinden sonra eser ortaya koyanlarca hemen hemen olduğu gibi günümüze taşınmıştır” (Oğuz, 2001: 8). Oğuz, tür tasniflerindeki karmaşıklığın sebeplerinden biri olarak “kuramsal düşünce” (Oğuz, 2001: 9) 
Sözlü Gelenekte Nesir Anlatıların Tür Sorunu

eksikliğini görür. Artık tür sorunu akademik bir konu olarak ele alınmalıdır. Bu konuda yapılan tanımlamalar, verilen bilgiler ezberlenmesi gereken "okul notları" olmaktan çıkarılmalıdır. Folklor ürünlerinin belli başlı tarihçelerinin, oluşum, gelişim, yayılma süreçleri ve coğrafyasının ortaya konulması kuramsal düşünce üretiminin alt yapısını oluşturacaktır. Herhangi bir folklor ürününün canlı ve güçlü biçimde yaşatıldığı geniş Türk coğrafyasında yerel adlandırma ve çeşitlemeleriyle çok fazla sayıda türün ortaya çıkacağı unutulmamalidir.

\section{SÖZLÜ GELENEĞIN NESIR ANLATILARINDA TÜR SORUNU}

Bir kültürün duygu ve düşüncelerini aktarmada kullandığı anlatıları, ait oldukları kategorilere göre aynı terimlerle ifade etme, bütün kültürlerde görülen bir durumdur. "Bu nedenle de, halkbilimciler veya kültürbilimciler, kültüre veya onun bir kısmına dair, dış̧tan bir bakış açısıyla (etic) analitik kategoriler olarak çözümlemeler yaparken ya yeni terimler ihdas etmekte veya kullanılan terimin karşıladığı kavramı tanımlamak yoluyla sınırlama ve açıklama getirerek ele almaktadırlar" (Çobanoğlu, 2007: 15). Folklor ürünlerinin türsel düzeyde sınıflandırılması, pek çok karışıklığı da beraberinde getirmiştir. Türsel adlandırmalar hangi ölçütler göz önünde bulundurularak yapılırsa yapılsın, yapılan her tanımlama bazı problemler taşıyacaktır. Yapılan değerlendirmeler dış gerçekliği bire bir yansıtmaktan çok, onu anlamlandırmaya yönelik bir soyutlama olmanın ötesinde bir anlam taşımayacaktır. Bir türün kendi içinde yapılacak sınıflandırmalarına benzer biçimde, türsel adlandırmaların kendisinde dahi “... sınıflandırma ölçütü olarak ileri sürülen kategorilerin arasında her zaman bir yönüyle bir kategoriye diğer yönüyle de diğer kategoriye yakın olup kolayllkla yer değiştirebilecek veya hiçbir kategoriye dahil edilmeyerek ayrı bir şemsiye terimle üçüncü bir kategoriye dahil edilebilecek unsurları çoğu kez bulmak mümkün..." (Çobanoğlu, 2007: 15)'dür.

Söylem türleri, sınırsız bir çeşitliliğe sahiptir. Bu sınırsız çeşitlilik söylem türlerinin heterojen bir yapıya sahip olmasını da beraberinde getirmiştir.

"Söylem türlerinin heterojenliği o kadar geniştir ki onlarl incelemek için tek bir düzlem yoktur, olamaz gibi görünür; ne de olsa, bir inceleme düzleminde karşımıza, tek sözcüklü gündelik replikler, birkaç ciltlik edebi roman, tonlamasında bile standart ve zorunlu askeri komut, derinlemesine benzersiz lirik eser gibi en heterojen olgular çıkar" (Bahtin, 2016: 66).

Söylem türlerindeki sorunların temelindeki nedenlerin biri bu heterojen yapıdır. Bahtin (2016: 68), her üslubun söylem türleriyle koparılmaz biçimde bağlantılı olduğunu söyler. Söylemsel iletişimin her alanında sözce bireyseldir ve bundan dolayı konuşanın/yazanın bireyselliğini 


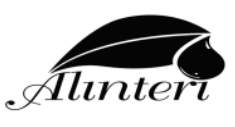

Cilt: 1 Sayı: 2 Yıl: 2017

yansıtır. Her tür, konuşanın/yazanın bireyselliğinin sonucudur. Bireysel üslupların belirlenmesi, söylem türlerinin çeşitliliğinin daha derinlemesine incelenmesini gerektirir. Üslubun türle organik bir bağ 1 vardır. "Her sahanın, özgül koşullarına karşılık gelen kendilerine ait türleri vardır ve bunları uygular. Bu türlere karşılık gelen belirli üsluplarl da vardır" (Bahtin, 2016: 69). Belirli bir işlev ve söylemsel iletişimin belirli koşulları, her saha için belirli türler doğurur. Üslubun olduğu her yerde tür vardır. Üslubun bir türden diğerine aktarılması türsel değişimleri doğurur. Üsluplar bir anlamda söylem türlerine hükmeder.

Folklor bir bilim olarak kabul edilmeye başlandığından beri araştırmacılar arasında mit, masal, efsane gibi anlatıların ne olduğu konusunda çok sayıda tanım yapılmıştır. Tüm kültürlerde mevcut bulunan bu kategoriler yanında bir de yerel kültürlerde olan türler vardır. Onların tür adı altında çeşitlenmesinde de benzer sorunlar vardır. Çoğu zaman halk biliminin nesir türleri gelişigüzel olarak tanımlanmaktadır. "Tanımlama ve sınıflandırmalar ne kendi içinde ilgi çekici, ne de gerektiği kadar verimli olmaktadır, fakat herhangi bir çalışma alanı temel terminolojisi açısından bir sinıflandırmaya ihtiyaç duyuyorsa, bu kesinlikle halk bilimidir ve halk bilimi çok uzun bir süredir tutarsız ve çelişkili tanımlamalar yüzünden sıkıntı çekmektedir" (Bascom, 2006: 114). Bascom mit, efsane ve masalları içeren sözel sanatın yaygın ve önemli olan bu üç türü için "nesir anlatı” (Bascom, 2006: 114) terimini önerir. Çünkü, nesir olmaları bu üç türün ortak özelliğidir; bu özellik onları atasözü, şarkı, şiir, tekerleme gibi diğer sözel sanat biçimlerinden ayırmaktadır.

Çeşitli türleri sınıflandırma ilk çağlardan beri edebiyatın konusu olmuş, günümüze kadar da bu konudaki çalışmalar devam etmiştir.

"Folklor araştırmalarındaki 18. asrın sonunda başlayan filolojik odaklanma, araştırmaların bu alanında belirleyici faktörü olarak türe çok önemli bir yer ayırmıştır. Burada da masal, destan, türkü, mani, atasözü ve muamma gibi klasik türlere ağırlık verilmiştir. Tür ve sinuflama; folklor eğitimi, öğretimi, arșivlenmesi ve koleksiyonu konularında şekillendirici çerçeve çalışmalarında temel farklılıklar oluşmuştur" (Bauman, 2006: 109).

Bauman tür terimini "gelenek hâline gelmiş bir sunum” (2006: 109) olarak tanımlar. Burada geleneksel özellik türün belirlenmesinde kilit rol oynar. Bir sunumun tür olarak kabul edilebilmesi için bir geleneğe sahip olması gerekir. Bauman yukarıdaki haliyle türü, belli bir sınıflama anlamında kullanmıştır. $\mathrm{Bu}$ terimle mit, destan, halk hikâyesi, masal, şiir gibi kategorileri birbirinden ayırmayı amaçlamıştır.

Herhangi bir nesne pek çok farklı nitelikle yüklenmiş olabileceği gibi, bir sözel nesir şekli de bir çerçevede ortaklık arz eden/etmeyen farklı türsel niteliklere sahip olabilir. Bundan dolayı türsel nitelikler, genel geçer birtakım 
niteliklerin "tür" kavramının inşasında kullanılmasından ziyade, anlatı nesnesinin ne olduğunu ortaya koyan edebî görüngüler olarak düşünülmelidir. Bir araştırmacının masal olarak aktarmaya başladığı bir anlatı, bir kişisinin kahramanlaştırılmasıyla destansı kılınabilir. Farklı halk anlatıları arasında da bu tür geçişler ve niteliksel kombinasyonlar her zaman gerçekleşebilir. Bu durumda, sınırları kesin çizgilerle çizilmiş birtakım türlerden bahsetmek zorlaşmaktadır. Kapsayıcı ve tek-tipleştirici türler yerine, anlatının üretildiği ve tüketildiği bağlamın yansıları olan türsel niteliklerden söz edilmelidir. Bir anlatı, bir türün içine dahil edilip edilmeme yerine kendi bütünlüğü içerisinde ve kendi nitelikleriyle ele alınmalıdır.

"İcrayı gerçekleştiren anlatıcının elindeki malzemenin sunduğu taslak yapı, bu taslak yapının anlatıcı tarafindan hem kendi kişisel tarihi, hem de içerisinde bulunduğu sosyokültürel bağlam çerçevesinde geliştirilmesi, performans esnasında dinleyici grubunun ördüğ̈̈ 'ses duvarı'nın karakteristiklerinin anlatıya etkisi türsel niteliklerin belirleniminde rol oynayan faktörlerdir. Bu hâlde, halk anlatısının türsel niteliklerini incelemenin yolu, anlatının üç bileşeninin göz önüne alınmasıyla gerçekleştirilebilir görünmektedir. Türsel niteliklerin bilinebilirliği, bu tür bir yaklaşımla ortaya konulacak daha kapsamlı bir başka çalışmayı gerektirmektedir" (Ulusoy Aranyosi, 2011: 17).

Sosyal bilimler tabiatı itibariyle fen bilimlerine benzer biçimde bir konuda her zaman kesin neticeler elde edilebilen bir bilim değildir. Fen bilimlerinde bir sorun üzerinde araştırmacıların ortak kanıya varacakları görüşler daha fazla iken, bu durum sosyal bilimler için daha esnek bir yapı sergiler. Öznellik sosyal bilimlerin doğasında bulunan bir niteliktir. Bascom "Fakat eğitimli ve düşünen insanlar net bir şekilde mit, efsane ve masalı birbirinden ayırırken..." (2006: 129) demesine rağmen, eğitimli insanların hatta işin uzmanları arasında bile- bazı ürünleri hangi tür başlık altında toplayacağına karar veremediği birçok durumla karşılaşırız. Aynı anlatının işin uzmanları tarafından farklı türler altında isimlendirilmesi çokça karşımıza çıkan bir durumdur. Bu durum olağan bir biçimde karşılanır hale gelmiştir. Sınıflandırmalar çoğu zaman kaygan bir zemine sahiptir. Ne tür bir sınıflandırma yapılırsa yapılsın, içinde sorun taşımayan bir sınıflandırmadan söz etmek güçtür. Bu durumda belki de en doğrusu mümkün olduğunca sınıflandırmaları azaltmaktır. Türlerin belirlenmesinde bir anlatının sahip olduğu temel ayırt edici niteliklerinin belirlenmesi sorunu biraz daha azaltabilir. Türlerin belirlenmesinde ayrıntılara girildikçe, türsel başlıklar arttıkça sınıflandırma ile ilgili sorunlar da aynı oranda artacaktır.

Folklor ürünlerinin nesir anlatılarını her araştırmacı kendince tanımlamıştır. Her araştırmacı, yaptığı yeni tanımlarla kendisinden önce yapılan tanımları daha karmaşık bir yapıya sokmuştur. Böyleye her yeni tür tanımlaması, çözüm getirmek yerine çözümü daha da zorlaştırmıştır. Bascom makalesini (2006) mit, efsane ve masal terimlerinin kullanımları konusunda 


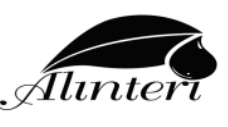

Cilt: 1 Sayı: 2 Yıl: 2017

halk bilimcilerin fikir birliğine ulaşmalarını sağlamak amacıyla yazdığını belirtirken, yapılan tanımlamalara bir tanımın da kendisi tarafindan yapılmasıyla konunun daha da karmaşık hale getirildiğinin farkında mıdır? $\mathrm{Bu}$ durum folklor ürünlerinin nesir anlatıları için geçerli olduğu gibi nazım türleri için de geçerlidir. Dünya üzerinde neredeyse araştırmacı sayısı kadar mit, masal, efsane vs. tanımları vardır. $\mathrm{Bu}$ tanımlar temelde bazı ortak özellikler taşımalarına rağmen hiçbiri diğerinin aynısı değildir. Herhangi bir araştırmacı sadece metinler üzerinde malzemeyi sınıflandırarak doğru bir neticeye varamaz. Yanlış bir tür sınıflandırması, beraberinde yanlış tanımlamaları da getirecektir.

Diğer milletlerin halk biliminde de bir sorun olarak duran tür problemi, Türk halk biliminde de bulunmaktadır. Özellikle Türk halk bilimi araştırmacılarının belli bir tür belirlemesinde Avrupal1-Amerikalı araştırmacıların kendi ürünleri üzerinde yaptıkları araştırmalara dayalı olarak yaptıkları tür tasnif ve tanımlamalarına bakarak kendi kültürümüzün ürünlerini bunlara uydurmaya çalışıp benzer tür tasnifleri yapmaları sorunu çözmek yerine daha da karmaşık bir yapıya sokmaktadır. Bir İsveç masalı birebir, bir Türk masalıyla örtüşmez; aynı nitelikleri taşımaz. Her kültür, halkını farklı biçimde şekillendirir. Bu durum, her halkın dünyaya, nesnelere bakışını, kendini tanımlayışını farklılaştıracaktır. Bu farklılıklar türlerin tanımını da değiştirecek, her toplumun kendine göre bir tür sınıflandırmasını doğuracaktır. $\mathrm{Bu}$ bakımdan belli bir anlatı bir Fransız için mit iken, bir Alman bunu masal veya efsane olarak tanımlayabilir. Belli bir türsel sınıflandırma yapmak temelinde yanlış değildir. Ancak her kültür için ortak bir tür tanımına ulaşmaya çalışmak yanlış olabilmektedir.

Folklor geleneğindeki çalışmalarda bulunan eksikliklerden biri de araştırmacıların çoğunlukla sadece eldeki metinlere göre değerlendirme yapmalarıdır. Metinler mutlaka kullanılmalıdır; ancak kullanımları, gelenekteki yerleri, anlatım ve yayılmaları da göz önünde bulundurulmalıdır (Sydow, 2010: 64). Bu yapıldığ 1 takdirde sözlü gelenekteki bir ürünün tüm kültürlerdeki tanımı aynı olmayacaktır. Bir tür, her kültürde farklı anlatım ve yayılım yasalarına bağlı olacağından, türsel konumu da farklı olacaktır. Folklor ürünleri incelemelerinin olmazsa olmazlarından biri bu ürünleri yaşadıkları konteks içinde değerlendirmektir.

Tür araştırmalarında bir metni ustasından derlemek önemlidir. Profesyonel olmayan kişilerden elde edilecek folklor ürünleri o ürünün türsel değerlendirilmesinde de birtakım yanlış sonuçlara ulaşılmasına neden olacaktır. $\mathrm{Bu}$ bakımdan bir ürünün türsel değerlendirilmesinde ürünün kimden alındığı çok önemlidir. Geleneği en iyi bilen ustalardan elde edilecek ürün ve bilgiler, en iyi şekle ulaşmayı sağlayacak ve böylece en doğru değerlendirmenin de kapısı aralanacaktır. 
Tür kavramı sözlü folklor ürünlerinin yanı sıra inanç ve uygulamalar, maddi objeler, müzik ve dans gibi folklor çeşitlerinde de kullanılmaktadır. Tür kelimesi tanımlanırken folklorik ürünlerin önemli görülen nitelikleri göz önünde bulundurulmuştur. Bir folklor ürününün şekli, fonksiyonu, muhtevası, kullanımı, hakikat değeri, sosyal dağıtımı önemli niteliklerinden birkaçıdır. XIX. asır araştırmacıları folklor ürünlerini eski zamanların sosyal norm ve uygulamalarının transformasyonu olarak görürken, $\mathrm{XX}$. asır folkloristleri, folklor ürünlerini bir veri olarak kabul edip onları açıklayıcı özellikleriyle nitelendirmeye başlar.

"Eski devirlerin atomistik ve nesnel yaklaşımından belirgin bir şekilde farkl olarak yeni tür konsepti 1) iletişimsel ürün/sunum ve kabulü düzenleyen karşıllklı münasebetlerin boyutlarını önemseyerek bütün sisteme tesir eden/sistemik; 2) esnek ve düzenlenebilir yönelimli araştırma çatıları olarak türlere bakan açı uçlu ve 3) sosyal hayatın idaresinde mantiki olarak sonuca varan uygulamaya odaklanan uygulama merkezli eğilim göstermektedir" (Bauman, 2006: 111).

Bir folklor üreticisi alışılmış beklentilere uygun davranabileceği gibi çeşitli türleri birleştirerek alışılmış beklentilerin dışına da çıkabilir. $\mathrm{Bu}$ durumda herhangi bir türe dâhil edemeyeceğimiz karma türler ortaya çıkar.

\section{TÜRLERARASILIK BAĞLAMINDA KARMA TÜRLER}

"Folklor metni kendine özgüdür, çünkü bu tür bir metin, insanlar arasındaki daha geniş bir sözlü ve geleneksel alışverişin, konuşulan, şarkısı söylenen, jestlerle ifade edilen ya da bir zanaat olan orijinal halinin yazılı temsilidir" (Titon, 2009: 262). Folklor olarak nitelendirilen bir ürün, dönüştürme ve yenileşmelere her zaman açıktır. Sözlü gelenek ürünlerinin tanımlanmasında araştırmacılar çoğunlukla, bir türü diğer türlerle karşılaştırma ve farkların saptanmasıyla bir tanıma ulaşma çabasına girmişlerdir. Bu tür tanımlama çabaları, sözlü gelenek ürünlerinin belirli özelliklerini ifade etmekte ise de, sözlü kültürün temel dinamikleri ile halk anlatıları arasındaki ilişkiyi her yönüyle kuşatan tanımlar olmaktan uzak görünmektedir. Ulusoy Aranyosi, halk anlatısını "üç düzlemin biraradalığında oluşan bağlamsal bir sözlü kültür nesnesi” (2011: 15) olarak tanımlarken, aynı zamanda üç düzlemin (anlatıcı/dinleyici/anlatı nesnesi = bağlam) türsel tanımlamalardaki vazgeçilmezliğini de vurgular.

Folklor türleri, farklı bağlamlarda, farklı biçimlere bürünebilen ve çeşitli değişimler/dönüşümler geçirebilen ürünlerdir. Âşık, hikâyesini aktarırken sadece ortaya koyduğu anlatı nesnesine odaklı değildir; kendi bireysel tarihi ve birikimi, hikâyesini dinleyen grubun özelliklerini dikkate alır. Anlatı bağlamsaldır; çünkü anlatı nesnesi, anlatıcı ve dinleyici grubu, içerisinde bulundukları bağlamların özelliklerini taşır. Anlatı sözlü kültür nesnesidir; çünkü icra edildiği ve yeniden üretildiği bağlam tarihsel, 


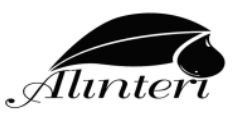

Cilt: 1 Sayı: 2 Yıl: 2017

toplumsal gelişme sürecinde yaratılan maddi ve manevi değerlerin ifade edildiği bir zemindir.

"Ĕ̈er anlatı[,] anlatı nesnesinin, anlatıcının ve dinleyici grubunun ortaklı̆̆ında oluşuyor ise, ortaya çıkan ürünün nitelikleri de doğal olarak bu bileşenlerle ilişkili olacaktır. Bu bileşenlerin anlatının oluşumundaki temel dinamikler olduğu ve bağlamsal değişkenlikleri hesaba katıldı̆̆ında, anlatının niteliklerinin de çok farkl kombinasyonlara sahip olabileceği ihtimali ortadadır" (Ulusoy Aranyosi, 2011: 16).

Sözlü edebiyatın kaynağı, folklor arşivleri değil, halkın hafızasıdır. Honko, "Ben bir metni, onun sosyal yapısı ve diğer ilgili olduğu ferdî ve ortalama duruma ait bilgilerden ayr bir şekilde analiz etmek istemiyorum" (2006: 93) der. Bir metnin türü belirlenirken onun gerçek oluşunun gözlemlenmesi ve diğer araştırmacıların gözlemlerinin bilinmesi gerekmektedir. K. V. Cistov'a göre tür "yeniden oluşum (reproduction) kurallarının bir sistemi" (akt. Honko, 2006: 93)'dir. Farklı türler demek, yeniden yapmanın kurallarının farklı sistemleri olduğunu belirtmiş olmaktır.

Folklor ürünleri, bir toplumdan diğerine geçişte, zaman içerisinde tür değişikliğine uğrayabilir. Masal efsaneye, mit masala vb. dönüşebilir veya her iki türün özellikleri bir arada bulunabilir. Aynı ürün bir toplumda mit, diğerinde masal, bir başkasında efsane olarak kabul edilebilir. Toplum içerisindeki bireylerin inançlarına bağlı olarak, ürünlere verilen adlar değişebilir. Aynı toplum içerisinde, aynı zaman diliminde dahi, inanç konusunda toplum bireyleri arasında bir birlik olması zordur. Bir toplumda çoğunluğun neye inandığını bilmek, o ürünü bir tür içine almada soru işaretlerine yol açabilir. Çünkü toplumun azınlığında, çoğunluğun inançlarına göre verilen hüküm kabul edilmeyecektir. Aralarında hiçbir zaman kesin çizgiler çizilmeyen ürünlerin türsel adlandırılmalarında farklı sınıflandırmaların yapılması kaçınılmazdır.

Herhangi bir folklor anlatının diğerlerinden kesin çizgilerle ayrıldığı durumlar vardır. Ancak bir anlatının, ikinci bazen üçüncü türün özelliklerini aynı anda taşıması, onu bir türsel ulama sokmayı güçleştirmektedir. Bir anlatının kutsal bir ortamdaki anlamı ile kutsal olmayan bir mekândaki anlatımı da türsel belirlemede soru işaretlerini getirmektedir. Araştırmacılar mevcut nesir anlatıları tanımlarken, her biri kendince bir tanım getirmiştir. Bascom miti tanımlarken sözlerine "Mit teriminden benim anladı̆̆ım ..." (2006: 128) diye başlar. "Masal terimiyle ... kastettim” (2006: 128) ifadesi de aynı şekilde bir belirsizlik içerir. Buradaki sorun, kimin neden ne anladığıysa, bir terimle ilgi sayısız tanım ortaya çıkacaktır. Bu yüzden folklor ürünlerini sınıflandırmada her zaman farklılıklar görülecek, ortak bir tür tarifinde uzlaşma sağlanamayacaktır.

Halk anlatısı, nesir şeklindeki sözlü edebiyatın tüm çeşitlerini kapsar. Folklor ürünleri, kendilerini herhangi bir yöresel ve sosyal havaya uyarlar. 
$\mathrm{Bu}$ ürünler hem geçmişe dayalıdır hem de yeni ve günceldir. Sözlü edebî ürünler bir taraftan basit, konuşma diliyle yaratılmış anlatılarken diğer taraftan karışık bir yapıya sahiptir. "Sözlü oldukları için, anlatı türleri sınırlı sayıdaki planların çerçevesindeki sınırsız çeşitlerin içerisinde bulunmaktadırlar. Dolaylsıyla tarza, içeriğe ve fonksiyonelliğe bağlı mükemmel bir sinıflandırma mümkün değildir" (Degh, 2006: 137). Sınıflandırmalar bilimsel çalışmanın kolay ve rahat olması için yapılmaktadır. Gerçek hayattan alınarak, soyut bir şekilde ele alınan ürünlerin tam bir sınıflandırmalarının yapılması mümkün değildir. Bir hikâye farklı farklı türlere uyabilir. Yukarıda da belirtildiği gibi, kültürel farklılıklardan dolayı bir kültür için masal olan ürün, diğeri için efsane olabilir. Trajik bir anlatıdaki hüzün birilerini üzerken, diğerleri için eğlendirici olabilir. Farklı şekillerde bulunan benzer karakterler, ayrıştırmayı zorlaştırabilir. İçerikle ilgili farklı anlamlandırmalar, tarzları da değiștirir. Bu değişim, dönüşüm ve farklılaşmalar sadece farklı kültür ve uzamlarda meydana gelmez. Aynı kültür içinde dahi farklı yaklaşımlar görülür. Folklor ürünlerinin grup ve bireylerin tutumlarına karşı duyarlılıkları, son şekillerinin olmaması, sürekli değişmeleri/yenileşmeleri türsel sınıflandırmaları anlamsız kılar. Sözlü ürünler, anlatıldıkları sürece çoğalır, çeşitlenir, birbirlerinin içine karışır. Sosyal değerlerinde meydana gelen değişimler, türsel dönüşümleri beraberinde getirir.

Günümüzde karışık/karma türler olarak adlandırılabilecek folklor ürünleri vardır. Örneğin bir masal değerini zamanla kaybederek şakaya, bir destan kültürlerarası yayılmalarda bir masala dönüşebilir. Tür karışımları farklı biçimlerde meydana gelebilmektedir. Türlerin basit birleşimlerinde bir tür diğerine karışır, bazen diğer türü yok eder. Bir tür böylece eski anlamını kaybeder, yeni bir sosyal çevre içerisinde yeniden oluşarak başka türle birlikte olur. Sanayi toplumlarındaki sosyal hayatın karmaşıklığıyla beraber, bu tür karışımlar çokça görülmektedir. Aynı olay örgüsü, değişik türlerde karşımıza çıkar. $\mathrm{Bu}$ noktada halk bilimciler, geleneksel toplumun eski sınıflandırmalarını bir tarafa bırakmalıdır. Kültürün anlam üzerindeki etkisini fark ederek yeni yaklaşımlar geliştirilmelidir. "Çağdaş yaşam, etraftaki tüm görüntüleri değiştirir. Halk bilimciler, eski türlerin azaltılarak, yerlerine yenilerinin konulmasi ve eskilere eklemeler yapllmasl gibi yeni kaynak ve ilerlemeleri iyice incele” (Degh, 2006: 151)'melidirler. Sözlü ürünler kültüre dayandıklarından dolayı çağdaş yaşam, değişkenlik ve kitlesel iletişimlerden etkilenirler. Ulaşım imkânlarının artması, haberleşme araçlarının yaygınlaşması halkı etnik bir topluluk olmaktan çıkarmış; toplumlar arasındaki ilişkileri daha karmaşık hale getirmiştir.

Herhangi bir anlatının türsel özelliği üzerinde durulurken, benzerliklerden değil, farklılıklardan hareket edilmelidir. Benzerlikler, türsel belirleyici değildir. Türleri belirleyen, bir şeklin diğer şekiller karşısındaki ayırt edici özellikleridir. Örneğin W. Burket miti “... sözlü geleneğe bağgl, 


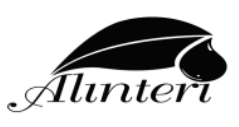

Cilt: 1 Sayı: 2 Yıl: 2017

akıcı ve yumuşak bir anlatım türü” (akt. Lüthi, 2006: 222) olarak tanımlar. Verilen tanım, sözlü geleneğin tüm türleri için geçerlidir. Bundan dolayı belirsiz ve ayırt edici değildir. Bu tarz tanımlamalar, türsel belirlemelerde yetersizdir.

M. Bakhtin'in "başkalarının sözlerinin dünyasında yaşıyorum” cümlesi türlerarasılık kavramına çok uygun düşmektedir. Türlerin karışımı ile metinlerarasılık kavramı arasında çok yakın bir ilişki vardır. Bir türün ortaya konulurken başka türlerden etkilenmesi, onlardan alıntılar yapması doğal ve kaçınılmaz bir durumdur. Sözel gelenekte türler arasında çok yakın bir ilişki vardır. Hiçbir tür yoktur ki başka türlerden etkilenmemiş olsun. Ancak bu etkilenmenin, bir anlatının türsel özelliğini ne derece etkilediği önemlidir. Belli oranda yapılan etkiler, türsel yapı üzerinde sarsılmalarla beraber bir değişim meydana getirmezken, bazı durumlarda bu etki türsel sınıfin yerini değiştirmektedir. Yapılan etkiye bağlı olarak ya eski türü yeni bir türe dönüştürür ya da melez bir tür ortaya çıkarır. Bu durumda "karışık/karma tür" denilen bir yapı meydana gelir. Bu yapıları zorlamalarla bir türe dâhil etmeye gerek yoktur. Bir anlatının içinde geçen belli bir türe ait motiflerin çokluğu, anlatıyı o türe dâhil etmek için yeterli değildir. Motifler de değişken bir yapıya sahip olduğundan girdiği türe uygun bir şekil kazanır; onun bir parçası olur. Titon folklor metinlerindeki kararsızlığın nedenlerinden biri olarak metinlerarasılığ 1 görür. Çünkü folklor metinlerinde otorite sahibi tek bir metin yoktur. Bir metnin birbirine benzeyen ve ilişki halinde olan birçok versiyonu vardır. Bu metinlerdeki kararsız yapının diğer nedeni de bu tür metinlerin gelişen, ilerleyen niteliğinden kaynaklanır (Titon, 2009: 268).

Bauman, türü “... konuşma stilinin bir düzeni...” (2009: 251) olarak tanımlar. Ona göre tür, belli tipteki bir metnin üretilmesine ve anlamlandırılmasına yönlendirilmiş bir söylem şeklidir. "Bir zamanlar" ile başlayan bir anlatı, söylemin kendine özgü beklenti kalıplarını da beraberinde taşır. Bu kalıp ifade bizi daha önce sunulan başka metinlere götürür. Bir metnin başka metinlerle temas ettiği sürece hayatiyetini devam ettirmesi, türsel değişimleri de etkiler. Her metin, bir başkasıyla diyalog halindedir. Metinler arasında gelişen bu diyalogun metnin türünü belirlemesi doğaldır. $\mathrm{Bu}$ bakımdan her metin bir taraftan önceki metinlere dayanırken, diğer taraftan gelecekte üretilecek metinleri tahmin etmeye yönlendirir. Bu durum "türsel metinlerarasılık” olarak adlandırılabilir. Bir metin "... başvurulan her türün biçimsel ve işlevsel kapasitelerinin oluşturulup karıştırıldı̆̆ birden fazla türsel çerçeveye benzeşmesine de yol açabilir” (Bauman, 2009: 255). Bu tür bir türsel karma, birçok basit türü emer, içine alır.

Taftalı, edebî ürünlerin ömründen bahsederken, insanın ölümlü bir varlık olması nedeniyle dünya algısının da "başlangıç ve son" ilişkisi içinde geliştiğini ifade eder. Ona göre "Edebi metnin yaşamı, onun okuyucuda uyandırdığı imgenin gücüyle orantılıdır” (Taftalı, 2015: 56). Edebi metnin gücü, onun tüketilmeyen metafizik özelliğinde gizlidir. Hayatta belli 
aralıklarla yapılan birçok eylem, bir zaman sonra tüketilir. Ancak bir edebi metin veya tür, her zaman bir yeniden üretim özelliğine sahiptir. Aynı metin sayısız kez yeniden üretilebilir. Edebi bir metin veya türün tükenmesi, onun yeniden üretilebilirliğinin tükenmesi anlamına gelmektedir.

Son dönemlerde ortaya atılan "hipermetin" kavramı da metin türleri üzerinde tekrar düşünmeyi zorunlu kılmaktadır. Hipermetin, kâğıt üzerinde değil de bilgisayar ekranında üretilen metindir. Hipermetinler doğrusal değillerdir ve birkaç yazı alanı ekranda eşzamanlı olarak görülebilir. J. Derrida'nın ifadesiyle “Bir 'metin' artık bitmiş bir yazı bütünü, bir kitabın ya da kitabın kenar boşluklarının arasına kapatılmış bir içerikten ibaret değil; metin artık farklılıklar üzerine kurulu bir ăg, kendinden başka bir şeye başka farklılık gösteren izlerle sonsuz kez atıfta bulunan bir izler sistemi" (akt. Titon, 2009: 275)'dir. Böylece metin için şu ana kadar yapılan bütün sınırlamalar ortadan kalmış olur. Bu yeni durum, yeni tür tanımlamalarını da zorunlu k1lar. Hipermetinler sayesinde sanatsal yazarlık ve okuma edimi cesaretlendirilirken, okuyuculara da yazarlık kapısını aralanır.

\section{SONUÇ}

Tür araştırmasında öncelikle bir araştırma stratejisi belirlenmelidir. $\mathrm{Bu}$, bir türün gelişim profilini ortaya koymada çeşitli veriler sunacaktır. İntratür, inter-tür, cros-tür kavramları, türlerin belirlenmesinde bizlere yardımcı olacak nitelikler verecektir. Türlerin belirlenmesinde yapı, muhteva, bağlam, üslup özelliklerine dikkat edilmelidir. Sözlü gelenekte her icra, yeni bir ürün ortaya koymadır. İrticalen icra edilen bir ürünün aynı şekilde ikinci bir aynısı yoktur. Hiçbir ağıt, halk hikâyesi, destan, masal vb. aynı şekilde ikinci defa icra edilemez. Her icra, bir yeniden yaratmadır. Bir folklor ürününün türsel belirlenmesinde biçimsel özellikler (şiir-düzyazı), geleneksel başlangıç/bitişler, anlatılma zamanı, inanırlılık, ürünün zaman ve mekânı, kabul edilme tavrı (kutsal/kutsal değil), temel karakterleri (insan/insan-dışı varlıklar) gibi nitelikler önemlidir. Anlatıların gerçek veya kutsal olarak kabul edilip edilmemesinde, değerlendiricilerin inançları değil, tarihsel veya bilimsel gerçeklerin yanı sıra, bilgiyi üreten, veren, yaşayanların ve dinleyenlerin inançlarına bakılmalıdır. Bu, nesnel bir gerçeklik değildir; bilgiyi verenlerin öznel gerçekliğidir.

Anlatı tipini dışarıdan belirlemek, doğru değerlendirmeler yapmaya engel olabilir. Folklor türlerinin yer, zaman, karakter gibi niteliklerinin yanında kendileriyle özdeşleşmiş olan inanç ve tavırları türsel belirlemelerde önemlidir. Folklor ürününün meydana geldiği sosyal ortam, anlatılma zamanı, yayılma esnasında anlatıcıya verdikleri yaratıcı özgürlük ayırt edici niteliklerindendir. Anlatıcı kimliği, dinleyici birliği, dinleyicilerin anlatıma katılımları, bu anlatıları kabullenme dereceleri türsel çeşitlenmede göz önünde bulundurulması gerekli özelliklerdir. Herhangi bir folklor türü sadece mit, sadece masal, sadece destan olmayabilir. Aynı anda birçok türü 


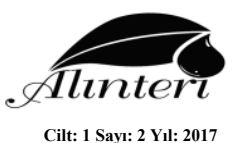

içerisinde barındırabilir ki bu tür örnekler çokça karşımıza çıkmaktadır. Türsel sınıflandırmalarda bir türü diğerlerinden kesin olarak ayıran nitelikler belirlenmelidir. Aynı nitelik başka ürünlerde bulunduğu sürece bu, türsel ayırımda bir fayda sağlamayacaktır. Türsel belirlemelerde ürünler arasında bulunan ortak niteliklerin bir değeri yoktur. Mitte doğaüstülüğün bulunması, hayvan ve bitkilerin kişileştirilmeleri onun türsel bir özelliği olmamalıdır. Çünkü bu özellikler, başka folklor ürünlerinde de bulunmaktadır.

Genetik olarak birbirine bağlı olan folklor nesir ürünlerini kesin çizgilerle ayırmak çok güçtür, aslında bazı durumlarda da gereksizdir. Folklor ürünlerinin türleri ilk anlatıldığı toplumlarda belirgin biçimde açıktır. Bir Kızılderilinin zihninde iki anlatı arasındaki fark her zaman kesin ve bellidir. Her kültür, halkını farklı biçimde şekillendirir. Bu durum, her halkın dünyaya, nesnelere bakışını, kendini tanımlayışını farklılaştıracaktır. $\mathrm{Bu}$ farklılıklar, türlerin tanımını da değiştirecek; her toplumun kendine göre bir tür sınıflandırmasını doğuracaktır. Bu bakımdan belli bir anlatı bir Fransız için mit iken, bir Alman için masal veya efsane olabilir. Belli bir türsel sınıflandırma yapmak temelinde yanlış değildir. Ancak, her kültür için ortak bir tür tanımına ulaşmaya çalışmak yanlıştır. Bir ürünün tür kavramında değerlendirilmesi için, belli bir geleneğe sahip olması gerekir. Anlatı nesnesi, anlatıcı ve dinleyicilerin bütününden meydana gelen bağlam da türsel belirlemelerde dikkate alınmalıdır.

\section{KAYNAKÇA}

AÇA, Mehmet. (2006). "Halk Şiirinde Tür ve Şekil”. Türk Halk Edebiyatı El Kitabı (ed. M. Öcal Oğuz). Ankara: Grafiker Yayıncılık. 263-314.

AÇA, Mehmet; A. Müge Ercan. (2006). “Anonim Halk Edebiyatı”. Türk Halk Edebiyatı El Kitabı (ed. M. Öcal Oğuz). Ankara: Grafiker Yayınc1lik. 113-168.

BAHTIN, Mihail M. (2016). Söylem Türleri ve Başka Yazılar (çev. Okan N. Çiftci). İstanbul: Metis Yayınları.

BASCOM, William R. (2006). "Folklorun Biçimleri: Nesir Anlatılar” (çev. R. Nur Aktaş vd.). Halk Biliminde Kuramlar ve Yaklaşımlar 1 (yay. hzl. M. Öcal Oğuz vd.). Ankara: Geleneksel Yayıncılık. 113-132.

BAUMAN, Richard. (2006). "Tür” (çev. Hülya Seyhan Sipahioğlu). Halk Biliminde Kuramlar ve Yaklaşımlar 1 (yay. hzl. M. Öcal Oğuz vd.). Ankara: Geleneksel Yayıncılık. 109-112.

BAUMAN, Richard. (2009). "Tür, Performans ve Metinlerarasılığın Üretimi” (çev. Işıl Altun). Halk Biliminde Kuramlar ve Yaklaşımlar 3 (yay. hzl. M. Öcal Oğuz vd.). Ankara: Geleneksel Yayıncılı. 249259. 
BORATAV, Pertev Naili. (1999). 100 Soruda Türk Halk Edebiyatı. İstanbul: Gerçek Yayınevi.

ÇOBANOĞLU, Özkul. (2000). Asşık Tarzı Kültür Geleneği ve Destan Türü. Ankara: Akçă̆ Yayınları.

ÇOBANOĞLU, Özkul. (2007). Türk Dünyası Epik Destan Geleneği. Ankara: Akçağ Yayınları.

DEGH, Linda. (2006). "Halk Anlatısı" (çev. Zerrin Karagülle). Halk Biliminde Kuramlar ve Yaklaşımlar 1 (yay. hzl. M. Öcal Oğuz vd.). Ankara: Geleneksel Yayıncılık. 133-152.

HONKO, Lauri. (2006). "Ağıtlar: Yeniden Yaratma, Yap1 ve Tür Problemleri” (çev. İsmail Görkem). Halk Biliminde Kuramlar ve Yaklaşımlar 1 (yay. hzl. M. Öcal Oğuz vd.). Ankara: Geleneksel Yayıncilik. 92-99.

LUTHI, Max. (2006). "Masalın Efsane, Menkabe, Mit, Fabl ve Fıkra Gibi Türlerden Fark1" (çev. Sevengül Sönmez). Halk Biliminde Kuramlar ve Yaklaşımlar 1 (yay. hzl. M. Öcal Oğuz vd.). Ankara: Geleneksel Yayıncilik. 220-222.

OĞUZ, M. Öcal. (2001). Halk Şiirinde Tür, Şekil ve Makam. Ankara: Akçağ Yayınlar1.

ONAY, Ahmet Talat. (1996). Türk Halk Şiirlerinin Şekil ve Nev'i. Ankara: Akçă̆ Yayınları.

RAYMAN, Hayrettin. (2010). Halk Edebiyatı Anlatı Türleri. Ankara: Gazi Kitabevi.

SYDOW, Carl Wilhelm V. (2010). “Coğrafya ve Masal Ekotipleri”. Halk Biliminde Kuramlar ve Yaklaşımlar 2 (yay. hzl. M. Öcal Oğuz, Selcan Gürçayır). Ankara: Geleneksel Yayıncılık. 61-70.

TAFTALI, Oktay. (2015). Edebi Söylem ve Varoluş. İstanbul: Mühür Kitaplığı1.

TITON, Jeff Todd. (2009). Metin. Halk Biliminde Kuramlar ve Yaklaşımlar 3 (yay. hzl. M. Öcal Oğuz vd.). Ankara: Geleneksel Yayıncılık. 260277.

ULUSOY ARANYOSİ, Ezgi. (2011). "Halk Hikâyelerinde Tür Sorunu Üzerine". Millî Folklor, 92, 13-18. 
